\title{
Are They Really Similar? Satisfaction, Opinion, and Scholarly Activity of Black Faculty by Citizenship Status
}

\author{
Patricia G. Boyer* \& Lorna Holtman ${ }^{1} *$ \\ *Correspondence: Ph.D. Associate Professor \\ University of Missouri-St. Louis \\ 269 Marillac Hall, St. Louis, MO 63121, USA \\ Tel: 1-314-516-7396_E-mail: boyerp@umsl.edu \\ ${ }^{1}$ * Ph.D., Associate Professor \\ Division for Postgraduate Studies, University of the Western Cape \\ Private Bag X17 Bellville, 7535, South Africa \\ Tel:1-272-1959-2451_E-mail:lholtman@uwc.ac.za
}

Received: January 18, 2012 Accepted: April 19, 2012 Published: June 24, 2012

doi:10.5296/ije.v4i2.1303 URL: http://dx.doi.org/10.5296/ije.v4i2.1303 


\begin{abstract}
Faculty workload is an important higher education issue because of its increasing demands on faculty time, mandates by institutional and external factors, and its relationship to job satisfaction. Specifically, how faculty perceive their workload can positively or negatively influence their job satisfaction. Current literature regarding faculty and workload has focused largely on workload models. The purpose of this study was to evaluate the workload of Black faculty members by citizenship status (U.S. citizens; citizens, foreign born; and non-citizens) based on satisfaction, opinion, and scholarly activity variables.

Overall, the findings revealed that foreign born and non-citizens were similar in many of the variables studied and U.S. born citizens were very different than the other two citizenship groups. In spite of the belief of many researchers, the findings revealed that in many variables studied, the U.S. born Black faculty were less productive and their opinions and satisfaction differ than foreign-born and non-citizens. Also revealed in this study, but not surprising, was the fact that approximately half of Black faculty were not in a tenured track position and a very small number had tenure. The findings will assist higher education institutions in better understanding Black faculty, in addition to, assisting administrators and policymakers in providing support toward enhancing the productivity of these faculty.
\end{abstract}

Keywords: job satisfaction, foreign born academics, non-citizens, U.S. citizens, workload, scholarly activities, opinions, campus issues 


\section{Introduction}

Academics face increasing demands on their time due to institutional and external factors. These demands are a result of the quality assurance regime, a new managerialism at higher education institutions, and competition for the appropriate student pool. Specifically, for example, as the number of students increase and the student population becomes more diverse, academics are faced with greater teaching loads and pressure to diversify teaching methods. Likewise, the new manageralism and the surge of students have increased the committee work and general administration duties of academics. Because time is limited, these additional duties effectively compromise research and other scholarly activities. As such, heavy workload can have an adverse effect on faculty output and job dissatisfaction.

In terms of who works in higher education, major demographic shifts are evident over the past three decades (Marvasti, 2005). Attractive job opportunities in technical areas (Marvasti, 2005), pure and applied sciences (Lin, Pearce \& Wang, 2008), among other areas have brought foreign-born faculty to American higher education. In spite of the increase in international faculty, little empirical research has been conducted to understand their experiences in the U.S. higher education system (Maimiseishvilli, n.d.). This paper is an examination of satisfaction levels, opinions, and scholarly activities of native born, foreign-born, and non-citizen Black academics in U.S. higher education institutions.

More specifically, a limited amount of research has been conducted on foreign born and/or international Black faculty, especially regarding the workload and scholarly activity. Moreover, Marvasti (2005) claims that even less is known about their teaching abilities. This study focuses on three specific areas: 1) job satisfaction level, 2) opinions of campus issues, and 3) scholarly activities of Black faculty based on their citizenship status. The purpose of this study was to determine if the selected 13 scholarly activity variables (i.e., hours/week serving on thesis/dissertation committees, recent published articles, and recent total publications) were statistically significant by citizenship status. Additional analyses were conducted to determine if faculty members by citizenship status were similar in opinion and satisfaction variables related to various campus issues, which focused largely on workload.

\subsection{Job satisfaction level and scholarly activities}

Job satisfaction has been shown to be an important factor in retention of faculty of color in higher education institutions (Turner, Sotello, González \& Wood, 2008; Laden \& Hagedorn, 2000; Ambrose, Huston, \& Norman, 2005; Gregory, 2001; Johnsrud \& Rosser, 2002) and the best predicator of turnover (Comm \& Mathaisel, 2003). In this regard, the literature reports that faculty are most satisfied with their autonomy (academic freedom) especially with regard to their decision making power in terms of what courses they teach, what content they choose to teach (Comm \& Mathaisel, 2003) but less satisfied with salary levels and other benefits (Stanley, 2006).

Workload is generally regarded as too high by many faculty in higher education institutions. Workload typically includes all teaching, research and service work conducted by faculty in a typical 48 to 52 hour working week (AAUP, n.d.) and has become an 
important institutional issue. Consequently, administrators need to understand workload as it relates to their faculty members in order to make better decisions regarding faculty workload. Also, the public wants to know how their tax dollars are spent at public higher education institutions and desire more accountability of faculty time. Additionally, faculty use workload measures for promotion and tenure and it is used to understand faculty roles in the academy (Meyer, 1998).

Faculty workload is important because of its relationship to job satisfaction. Higher education institutions should be especially concerned with the job satisfaction of faculty of color because of the time and money spent in recruiting and retaining them. If faculty of color are not satisfied, then it may have a negative impact on their productivity in the academy. Literature regarding faculty and workload has focused largely on workload models such as institutions attempt to improve job satisfaction and manage workloads more effectively (Vardi, 2009), job satisfaction and workload, decline in collegiality, and academic autonomy ('academic freedom') (See Anderson, Johnson \& Saha, 2002). The time consumed in all of these activities influence faculty workload; coupled this with the poor recognition of the efforts of faculty which negatively impacts work performance and demoralised them. Anything that is seen as a hindrance to pursuing scholarly activities and teaching affects the overall job satisfaction- these include factors closely related to workload such as teaching more students and more courses or teaching outside of one's field of expertise (McInni as cited by Vardi, 2009). More specifically with regard to Black female faculty, Stanley (2006) reports that they are more likely to be involved in teaching, advising, and committee work than their White colleagues (both male and female) and spend less time on scholarly activities. Gregory (1999) argues that Black faculty engage in research that is often considered as risky and less rigorous.

\section{Theoretical Framework}

In an attempt to increase the number of faculty of color on our campuses, we have surpassed our knowledge and understanding of their experiences. Data revealed that faculty of color tend to be employed at less prestigious institutions and at the lower end of the faculty rank. Information such as institutional factors, personal and professional needs, and interests are crucial in understanding faculty of color and is lacking in the literature (Olsen, et al., 1995).

The theoretical framework utilized in this study is based on the work of Herzberg, who developed a theory based on factors that motivate employees on the job. This theory includes five factors which are strong determinants of job satisfaction (Gawel, 1997). These factors are achievement, recognition, the work itself, responsibility, and advancement. Maslow expanded on Herzberg's theory by ranking human needs and explaining how people pursue these needs (Gawel). Based on Herzberg's work, faculty can be dissatisfied and unmotivated, satisfied and unmotivated, or satisfied and motivated (Gawel). Of course, we would like to see faculty at the last stage, satisfied and motivated, because they are more likely to persist and be productive. 


\section{Methodology}

Data analyzed for this study were from the National Center for Education Statistics' (NCES) National Study of Postsecondary Faculty (NSOPF: 04) database. Data were collected from the sampled faculty in a multistage effort. Approximately 26,100 faculty and instructional staff from 865 postsecondary institutions completed the self-reported survey (U.S. Department of Education, 2006). The sample size for this study is 1,890 faculty members from NSOPF: 04 and consist of individuals who identified themselves as Black faculty. Data were analyzed using SAS Statistical Tools and Thomas and Heck's (2001) research that is appropriate for handling large and complex data. The margin of error for this study is at the $\mathrm{p}<.05$ level.

The purpose of this study was to determine if Black faculty members differ in their satisfaction, opinion, and scholarly activity variables based on citizenship status (U.S. citizens; citizens, foreign born; and non-citizens). The 13 scholarly activity variables (i.e., hours/week serving on thesis/dissertation committees, recent published articles, and recent total publications) were statistically significant by citizenship type. Additional analyses were conducted to determine if faculty members by citizenship status were similar in their opinion and satisfaction levels related to various campus issues, which focused largely on workload. Specifically, the research questions that are germane to this study were as follows: 1) Are there statistically significant differences in the 13 scholarly activity variables (i.e., hours/week serving on thesis/dissertation committees, recent published articles, and recent total publications) by citizenship type among Black faculty and 2) Are there statistically significant differences in opinion and satisfaction levels related to various campus issues as expressed by Black faculty of various citizenship types. Only faculty members who stated they have faculty status and who do not perform administrative duties were selected for this study.

\subsection{Findings}

The demographics for this study were tenure status, gender and citizenship status (See Table 1). There were a total of 1,890 faculty members in this study of which $80 \%$ were U.S. citizens, $12 \%$ were foreign born citizens, and $8 \%$ were non-citizens. The majority of the faculty members were female $(53 \%)$ and not on tenure track $(48 \%)$. We did not distinguish between part-time and full-time faculty.

The majority of faculty members who are U.S. citizens were employed at two-year institutions $(55 \%)$ but the majority of foreign-born $(61 \%)$ and non-citizen $(73 \%)$ were employed at four-year institutions. Foreign-born faculty members (32\%, 11-20 years) have been on the job longer than citizens (19\%, 1-year) and non-citizens (17\%, 1-year). Also, faculty members who are foreign-born and non-citizens have more scholarly activity $(58 \%$ \& $75 \%$, respectively) than U.S. born (41\%) (See Table 1). 


\section{Macrothink}

Table 1: Demographics of Tenure Status, Gender, and Citizenship Status

\begin{tabular}{|c|c|c|}
\hline Variable & Frequency & Percentage \\
\hline \multicolumn{3}{|l|}{ Tenure status } \\
\hline Tenured & 450 & 23.80 \\
\hline On tenured track & 320 & 16.76 \\
\hline Not on tenure track & 900 & 47.86 \\
\hline No tenure system & 220 & 11.58 \\
\hline \multicolumn{3}{|l|}{ Gender } \\
\hline Male & 880 & 46.64 \\
\hline Female & 1010 & 53.36 \\
\hline \multicolumn{3}{|l|}{ Citizenship status } \\
\hline Citizen, born in U.S. & 1520 & 80.12 \\
\hline Citizen, foreign born & 230 & 12.32 \\
\hline Non-citizen & 140 & 7.56 \\
\hline \multicolumn{3}{|l|}{ Type of institution employed } \\
\hline U.S. citizen, 4-year & 680 & 44.55 \\
\hline U.S. citizen, 2-year & 840 & 55.45 \\
\hline Foreign-born, 4-year & 140 & 60.94 \\
\hline Foreign-born, 2-year & 90 & 39.06 \\
\hline Non-citizen, 4-year & 100 & 72.73 \\
\hline Non-citizen, 2-year & 40 & 27.27 \\
\hline \multicolumn{3}{|l|}{ Years held current job } \\
\hline $1-2$ & 590 & 31.14 \\
\hline $3-4$ & 330 & 17.50 \\
\hline $5-6$ & 210 & 11.26 \\
\hline $7-8$ & 140 & 7.29 \\
\hline $9-10$ & 110 & 5.55 \\
\hline $11-20$ & 330 & 17.29 \\
\hline $21+$ & 190 & 9.94 \\
\hline \multicolumn{3}{|l|}{ Scholarly activity } \\
\hline \multicolumn{3}{|l|}{ Citizen, born in U.S. } \\
\hline No & 890 & 58.75 \\
\hline Yes & 630 & 41.25 \\
\hline \multicolumn{3}{|l|}{ Citizen, foreign born } \\
\hline No & 100 & 42.06 \\
\hline Yes & 130 & 57.94 \\
\hline \multicolumn{3}{|l|}{ Non-citizen } \\
\hline No & 40 & 25.17 \\
\hline Yes & 110 & 74.83 \\
\hline
\end{tabular}

Source: National Center for Statistics, 2004 National Study of Postsecondary Faculty

IES/NCES requires restricted data sample size to be rounded to the nearest 10 
Presented in Table 2 are the 13 variables (i.e., hours/week serving on thesis/dissertation committees, recent published articles, and recent total publications) studied regarding Black faculty members' scholarly activities based on citizenship status. Faculty members who were foreign born citizens had 6 of 13 variables with the highest number of total means for scholarly activity ( $\mathrm{M}$ hours/week on thesis/dissertation committees $=1.14$; $\mathrm{M}$ recent articles, non-refereed journals=1.11; $\mathrm{M}$ recent presentations=4.11; $\mathrm{M}$ recent patents, computer software $=0.13 ; \mathrm{M}$ career total publications/scholarly works $=20.26 ; \mathrm{M}$ recent total publications, exhibitions, or performances $=5.10$ ). Non-citizens had 5 of 13 variables with the highest number of total means for scholarly activity ( $M$ hours/week, administrative committee $=2.80 ; \mathrm{M}$ recent articles, refereed journals $=2.00 ; \mathrm{M}$ recent book reviews, chapters, creative works $=0.79 ; \mathrm{M}$ recent books, textbooks, reports $=0.53 ; \mathrm{M}$ recent total publications/scholarly works=4.34). U.S. born citizens had one two variables ( $\mathrm{M}$ recent exhibitions performances $=1.44$ and $\mathrm{M}$ career total presentations, exhibit, or performance $=33.79$ ) that were high for scholarly activity.

Table 2: Means and Standard Deviations of Faculty Members' Scholarly Activity by Citizenship Status

\begin{tabular}{lllc}
\hline Variable & $\begin{array}{l}\text { U.S. Born } \\
\mathrm{n}=1520 \$\end{array}$ & $\begin{array}{l}\text { Foreign born } \\
\mathrm{n}=230 \$\end{array}$ & $\begin{array}{l}\text { Non-citizen } \\
\mathrm{n}=140 \$\end{array}$ \\
\hline Hours/week, theses/dissertations comm & $0.79(2.54)$ & $1.14(3.09)$ & $1.04(2.22)$ \\
Hours/week, administrative comm & $2.33(4.77)$ & $2.21(3.93)$ & $2.80(4.32)$ \\
Recent articles, refereed journals & $0.58(1.82)$ & $1.14(2.49)$ & $2.00(4.59)$ \\
Recent articles, non-refereed journals & $0.71(2.37)$ & $1.11(2.40)$ & $1.01(3.00)$ \\
Recent book reviews, chapters, creative works & $0.33(1.10)$ & $0.50(1.21)$ & $0.79(2.19)$ \\
Recent books, textbooks, reports & $0.33(1.38)$ & $0.45(1.38)$ & $0.53(1.88)$ \\
Recent presentations & $3.35(6.45)$ & $4.11(7.66)$ & $3.14(4.66)$ \\
Recent exhibitions, performances & $1.44(7.16)$ & $0.98(4.93)$ & $0.69(4.37)$ \\
Recent patents, computer software & $0.06(0.55)$ & $0.13(0.78)$ & $0.05(0.36)$ \\
Career total publications/scholarly works & $10.74(27.82)$ & $20.26(39.66)$ & $18.73(34.71)$ \\
Recent total publications/scholarly works & $1.95(4.36)$ & $3.20(5.10)$ & $4.34(7.56)$ \\
Recent total publications, exhibitions, or & $4.79(10.23)$ & $5.10(10.49)$ & $3.84(6.44)$ \\
performances & & & \\
Career total presentations, exhibit, or perform & $33.79(88.67)$ & $28.87(65.65)$ & $19.33(35.27)$ \\
\hline
\end{tabular}

Source: National Center for Statistics, 2004 National Study of Postsecondary Faculty

\$IES/NCES requires restricted data sample size to be rounded to the nearest 10

In an attempt to determine if the 13 scholarly activity variables were statistically significantly different by citizenship type, an analysis of variance (ANOVA) was performed. Five of the 13 variables were statistically significantly different: recent articles, refereed journals $(\mathrm{F}=29.98, \mathrm{p}=0.0001)$; recent articles, non-refereed journals $(\mathrm{F}=3.48, \mathrm{p}=0.0309)$; recent book reviews, chapters, creative works $(\mathrm{F}=10.71, \mathrm{p}=0.0001)$; career total 
publications/scholarly works $(\mathrm{F}=13.42, \mathrm{p}=0.0001)$; and recent total publications/scholarly works $(\mathrm{F}=21.34, \mathrm{p}=0.0001)$ (See Table 3$)$.

An additional analysis was conducted to determine if faculty members by citizenship status were similar in their opinion and satisfaction levels related to various campus issues. An ANOVA was conducted and 8 out of 14 variables studied were significant. The variables were: any scholarly activity $(\mathrm{F}=38.97, \mathrm{p}=0.0001)$; satisfaction with workload $(\mathrm{F}=3.90, \mathrm{p}=0.0203)$; satisfaction with salary $(\mathrm{F}=38.97, \mathrm{p}=0.0001)$; satisfaction with benefits $(\mathrm{F}=38.97, \mathrm{p}=0.0001)$; satisfaction with job overall $(\mathrm{F}=38.97, \mathrm{p}=0.0001)$; opinion about teaching is rewarded $(\mathrm{F}=38.97, \mathrm{p}=0.0001)$; opinion about how part-time faculty are treated $(\mathrm{F}=38.97, \mathrm{p}=0.0001)$; and opinion about racial minorities treated fairly $(\mathrm{F}=38.97, \mathrm{p}=0.0001)$ (See Table 3).

Table 3: Analysis of Variance of Faculty Members' Scholarly Activity

\begin{tabular}{lccc}
\hline Variable & Sum of Squares & F-value & p-value \\
\hline Hours/week, thesis/dissertations comm & 28.71 & 2.13 & 0.1190 \\
Hours/week, administrative comm & 34.31 & 0.80 & 0.4509 \\
Recent articles, refereed journals & 301.01 & 29.98 & $0.0001^{* * *}$ \\
Recent articles, non-refereed journals & 41.17 & 3.48 & $0.0309^{*}$ \\
Recent book reviews, chapters, creative & 32.18 & 10.71 & $0.0001^{* * *}$ \\
works & & & \\
Recent books, textbooks, reports & 7.18 & 1.75 & \\
& & 0.1734 & \\
Recent presentations & 130.81 & 1.55 & 0.2129 \\
Recent exhibitions, performances & 104.41 & 1.15 & 0.3181 \\
Recent patents, computer software & 1.09 & 1.67 & 0.1884 \\
Career total publications/scholarly works & & 13.42 & $0.0001^{* * *}$ \\
Recent total publications/scholarly works & & 21.34 & $0.0001^{* * *}$ \\
Recent total publications, exhibitions, or performances & 0.74 & 0.4761 \\
Career total presentations, exhibitions, or performances & 2.17 & 0.1144 \\
\hline
\end{tabular}

Source: National Center for Statistics, 2004 National Study of Postsecondary Faculty

$* \mathrm{p}<.05 ; * * \mathrm{p}<.01 ; * * * \mathrm{p}<.001$

$\mathrm{df}=(2,1890)$

The first variable in Table 4 indicates whether the faculty member is involved in scholarly activities $(0=$ no scholarly activities; $1=$ have scholarly activities). All three groups of Black faculty stated that they are involved in some form of scholarly activities. Also presented in Table 4 are variables about the satisfaction level of faculty (example of variables are equipment/facilities, salary, and job overall). Six variables (authority to make decisions, technology-based activities, equipment/facilities, institutional support for teaching 
improvement, workload, \& job overall) out of eight variables studied revealed that all three groups of faculty are very satisfied with them. Only two satisfaction variables (salary \& benefits) of the eight variables revealed that Black faculty were somewhat satisfied with them. In reference to their opinions about the campus environment, faculty members who were citizens strongly agreed with all five opinion variables (teaching is rewarded, part-time faculty treated fairly, female faculty treated fairly, racial minorities treated fairly \& about choosing the same academic career again); foreign born citizens strongly agreed with two opinion variables (female faculty treated fairly \& about choosing the same academic career again) and somewhat agreed on the other three variables; and for non-citizens, they strongly agreed with four opinion variables (teaching is rewarded, female faculty treated fairly, racial minorities treated fairly \& about choosing the same academic career again) and somewhat agreed with one variable (part-time faculty treated fairly).

Table 4: Means and Standard Deviations of Faculty Members' Satisfaction and Opinion Variables by Citizenship Status

\begin{tabular}{llll}
\hline Variable & $\begin{array}{l}\text { U.S. Born } \\
\mathrm{n}=1520 \$\end{array}$ & $\begin{array}{l}\text { Foreign } \\
\text { born } \\
\mathrm{n}=230 \$\end{array}$ & $\begin{array}{r}\text { Non-citizen } \\
\mathrm{n}=140 \$\end{array}$ \\
\hline Any scholarly activity & $\begin{array}{l}0.41(0.49) \\
0.58(0.49)\end{array}$ & $0.75(0.43)$ \\
Satisf with authority to make decisions & $1.27(0.88)$ & $1.29(0.82)$ & $1.31(0.99)$ \\
Satisf with technology-based activities & $1.53(1.03)$ & $1.62(0.98)$ & $1.54(1.06)$ \\
Satisf with equipment/facilities & $1.73(1.13)$ & $1.69(1.12)$ & $1.61(1.23)$ \\
Satisf w/instit support for teaching improvement & $1.79(2.54)$ & $1.94(3.09)$ & $1.95(2.22)$ \\
Satisf w/workload & $1.78(0.84)$ & $1.83(0.90)$ & $1.97(0.83)$ \\
Satisf w/salary & $2.25(0.96)$ & $2.51(0.99)$ & $2.51(0.92)$ \\
Satisf w/benefits & $2.12(1.01)$ & $2.29(1.02)$ & $2.32(0.88)$ \\
Satisf w/job overall & $1.61(0.71)$ & $1.83(0.76)$ & $1.88(0.73)$ \\
Opin: teaching is rewarded & $1.90(0.89)$ & $2.11(0.99)$ & $1.89(0.81)$ \\
Opin: P/T faculty treated fairly & $1.98(0.92)$ & $2.26(0.99)$ & $2.18(0.93)$ \\
Opin: female faculty treated fairly & $1.69(0.81)$ & $1.68(0.80)$ & $1.59(0.65)$ \\
Opin: racial minorities treated fairly & $1.83(0.88)$ & $2.02(0.95)$ & $1.94(0.89)$ \\
Opin about choosing an academic career agn & $0.89(0.30)$ & $0.90(0.30)$ & $0.90(0.30)$ \\
\hline Source: National Center for Statistis, 2004 Natis
\end{tabular}

Source: National Center for Statistics, 2004 National Study of Postsecondary Faculty $\$$ IES/NCES requires restricted data sample size to be rounded to the nearest 10 $* \mathrm{p}<.05 ; * * \mathrm{p}<.01 ; * * * \mathrm{p}<.001$

Note: Possible responses are "1=Very satisfied"; "2=Somewhat satisfied"; "3=Somewhat dissatisfied"; "4=Very dissatisfied"

Note: Possible responses are "1=Strongly agree"; "2=Somewhat agree"; "3=Somewhat disagree"; "4=Strongly disagree" 
The analysis of variance for the satisfaction and opinion variables revealed that 8 of the 14 variables studied were statistically significantly different. Black faculty based on citizenship status differ in the following variables: any scholarly activity $(\mathrm{F}=38.97, \mathrm{p}=0.0001)$; satisfaction with workload $(\mathrm{F}=3.90, \mathrm{p}=0.0203)$; satisfaction with salary $(\mathrm{F}=10.73, \mathrm{p}=0.0001)$; satisfaction with benefits $(\mathrm{F}=5.11, \mathrm{p}=0.0001)$; satisfaction with job overall $(\mathrm{F}=17.29$, $\mathrm{p}=0.0001)$; opinion that teaching is $\operatorname{rewarded}(\mathrm{F}=5.44, \mathrm{p}=0.0044)$; opinion that part-time faculty are treated fairly $(\mathrm{F}=10.70, \mathrm{p}=0.0001)$; and opinion that racial minorities are treated fairly $(\mathrm{F}=5.23, \mathrm{p}=0.0054)($ See Table 5).

Table 5: Analysis of Variance of Faculty Members' Satisfaction and Opinion Variables

\begin{tabular}{lccc}
\hline Variable & $\begin{array}{c}\text { Sum of } \\
\text { Squares }\end{array}$ & F-value & p-value \\
\hline Any scholarly activity & 18.61 & 38.97 & $0.0001^{* * *}$ \\
Satisf with authority to make decisions & 0.30 & 0.19 & 0.8241 \\
Satisf with technology-based activities & 1.65 & 0.79 & 0.4559 \\
Satisf with equipment/facilities & 1.82 & 0.76 & 0.4694 \\
Satisf w/instit support for teaching improvement & 7.66 & 2.98 & 0.0509 \\
Satisf w/workload & 5.61 & 3.90 & $0.0203^{*}$ \\
Satisf w/salary & 19.82 & 10.73 & $0.0001^{* * *}$ \\
Satisf w/benefits & 10.32 & 5.11 & $0.0001^{* * *}$ \\
Satisf w/job overall & 17.66 & 17.29 & $0.0001^{* * *}$ \\
Opin: teaching is rewarded & 8.79 & 5.44 & $0.0044 * *$ \\
Opin: P/T faculty treated fairly & 18.43 & 10.70 & $0.0001^{* * *}$ \\
Opin: female faculty treated fairly & 1.33 & 1.05 & 0.3504 \\
Opin: racial minorities treated fairly & 8.27 & 5.23 & $0.0054^{* *}$ \\
Opin about choosing an academic career agn & 0.01 & 0.06 & 0.9449 \\
\hline Source: Nati
\end{tabular}

Source: National Center for Statistics, 2004 National Study of Postsecondary Faculty $\mathrm{df}=(2,1890)$

$* \mathrm{p}<.05 ; * * \mathrm{p}<.01 ; * * * \mathrm{p}<.001$

\section{Conclusions and Implications}

The purpose of this study was to determine if Black faculty members based on citizenship status differ in their satisfaction, opinion, and scholarly activity variables. According to the means of foreign born and non-citizen status, Black faculty were similar in their scholarly workload. These two groups spent more hours per week conducting service and recent workload than U.S. born Black faculty. U.S. born citizens had the highest number of exhibition or performances and career total presentations. 
Overall, the ex post facto examinations revealed that foreign born and non-citizens were similar in many of the variables studied. Also, U.S. born citizens were very different than foreign-born and non-citizens with many variables studied. In spite of the belief of many researchers, the findings revealed that in many variables studied, U.S. born Black faculty were less productive and their opinions and satisfaction levels differ from that of foreign-born and non-citizens. One reason for this difference could be due to the findings by some researchers who claim that faculty of color are not always invited to collaborate with colleagues on scholarly work. This is true for native born faculty and not the other two groups studied.

Similar research was conducted by Marvasti in 2005 studying comparable variables but using data from the U.S. Department of Education. One difference between the two studies is that he studied native born and foreign born faculty and not just Black faculty. The findings of the present study were consistent with Marvasti's research for many of the variables. In summarizing the findings of the two studies, not much has changed over the years for Black faculty in regards to their relationship with colleagues, satisfaction levels at institutions, and their perceptions about their opinions being respected.

In this study, U.S. born citizens were statistically significantly different on some variables than their counterparts. In spite of the belief of many researchers, the findings revealed that in many variables studied U.S. born Black faculty were less productive in scholarly activities. Specifically, non-citizens published almost twice as many recent articles in refereed journals, almost twice as many total publications, and about three times more recent total publications than U.S. born Black faculty. According to Mamiseishvili (n.d.), foreign born Black faculty must outperform U.S. Black faculty in order to be competitive for employment at institutions of higher education in the U.S. and do not have the same requirement of service activities. Additionally, the results of this study revealed that U.S. born Black faculty are less satisfied when compared to their counterparts. As previously stated, service compromises research and other scholarly activities and can negatively affect faculty output and job satisfaction. It is beyond the scope of this research to determine if service work conducted by U.S. born Black faculty is a possible cause for the difference in scholarly productivity. Many questions about U.S. born Black faculty were raised based on the results of this study. Future research should focus on these issues possibly by conducting qualitative research and looking at more service activities of Black faculty.

It is important for administrators to understand Black faculty because they can be role models for minority students and other faculty of color. Because many resources are used in recruiting faculty of color, retaining them is very important especially in some geographical areas and fields of study. Also, it is important to understand the beliefs, perceptions, and attitudes of Black faculty because it will assist in recruiting and retaining them. The findings of this research can benefit institutions in this endeavor. Keep in mind, if Black faculty are satisfied and productive, they are more likely to persist at the institution and eventually be rewarded promotion and tenure. 
Another important issue to consider from the current study is the fact that almost half of them are not in a tenured track position but approximately one quarter of them are tenured. It is very alarming, to say the least, that so many Black faculty are not on tenure track. Once again, it is beyond the scope of this study but must be further investigated.

Another finding worth noting is the fact that all three groups stated they were very satisfied or somewhat satisfied that racial minorities were treated fairly. Also, the majority of the academics in this study were women and they were very satisfied with the treatment of female faculty. One must be careful in interpreting the findings of this study as it relates to scholarly productivity because there is no single definition to measure or understand this variable.

The findings of this study will contribute to understanding of Black faculty who are citizens, foreign-born and non-citizens employed in the U.S. Also, it will assist administrators and policymakers in providing support toward enhancing the productivity of Black faculty which could potentially affect their persistence and productivity in higher education. It is important for institutions to be cognizant about how to develop young faculty of color. Administrators must not assume that untenured faculty members have been appropriately trained in how to publish. It is essential to make sure that Black faculty and other faculty of color are a planned priority at your institution. As has been reported in a plethora of research related to faculty of color, formal and informal mentoring must be a part of the planned priority. Finally, according to Blackburn, Wenzel, and Bieber (1994), as cited in Stanley "higher education institutions, ...need to focus on the experiences of faculty of color if we hope to understand the work environments needed to support creative talents" ( $\mathrm{p}$. 702).

\section{References}

AAUP. (n.d.). Faculty work and workload. Retrieved from http://www.aaup.org/AAUP/issues/facwork/

Ambrose, S., Huston, T., \& Norman, M. (2005, September 19). A qualitative method for assessing faculty satisfaction. Research in Higher Education, 46(7), 803-830. http://dx.doi.org/10.1007/s11162-004-6226-6

Anderson, D., Johnsson, R., \& Saha, L. (2002). Changes in academic work: Implications for universities of the changing age distribution and work roles of academic staff. Retrieved from http://www.dest.gov.au/archive/highered/otherpub/academic_work.pdf

Comm, C.L., \& Mathaisel, D.F.X. (2003). A case study of the implications of faculty workload and compensation for improving academic quality. The International Journal of Educational Management, 200-210. http://dx.doi.org/10.1108/09513540310484922

Gawel, Joseph E. (1997). Herzberg's theory of motivation and Maslow's hierarchy of needs. Practical Assessment, Research \& Evaluation, 5(11). Retrieved from http://PAREonline.net/getvn.asp?v=5\&n=11 
Gregory, S. (1999). Black women in academe: Progress but no parity. Journal of Advancing Women in Leadership. Retrieved from http://www.advancingwomen.com/publichtml/gregory.html

Gregory, S.T. (2001, Summer). Black faculty women in the academy: History, status, and future. The Journal of Negro Education, 70(3), 124-138. http://dx.doi.org/10.2307/3211205.

Johnsrud, L.K., \& Rosser, V.J. (2002, Jul-Aug). Faculty members' morale and their intention to leave: A multilevel explanation. The Journal of Higher Education, 73(4), 518-542. DOI: $10.1353 /$ jhe.2002.0039

Laden, B.V., \& Hagedorn, L.S. (2000, Spr). Job satisfaction among faculty of color in academe: Individual survivors or institutional transformers? New Directions for Institutional Research, 27(1), 57-66.

Lin, Z., Pearce, R., \& Wang, W. (2009). Imported talents: Demographic characteristics, achievement and job satisfaction of foreign born full time faculty in four-year American colleges. Higher Education, 57(6). http://dx.doi.org/10.1007/s10734-008-9272-z.

Mamiseishvili, K. (n.d.) International faculty in the U.S.: An examination of their workload productivity and satisfaction. Retrieved from http://www.airweb.org/images/Mamiseishvili_727_proposal.pdf

Marvasti, A. (2005, March). U.S. academic institutions and perceived effectiveness of foreign-born faculty. [Online]. Journal of Economic Issues, XXXIX, 1, 151-175.

Meyer, K. A. (1998). Faculty Workload Studies: Perspectives, Needs, and Future Directions. ASHE-ERIC Higher Education Report, 26(1). Washington, DC: Graduate School of Education and Human Development, George Washington University.

National Center for Education Statistics. (2006, May). 2004 National Study of Postsecondary Faculty (NSOPF:04) Methodology Report. Retrieved from NCES web site http://nces.ed.gov/pubs2006/2006179.pdf

Olsen, D., Maple, S.A., \& Stage, F.K. (1995, May-June). Women and minority faculty job satisfaction: Professional role interests, professional satisfactions, and institutional fit. Journal of Higher Education, 66(3), 267-293. Retrieved from http://www.questia.com/googleScholar.qst?docId=5001648461

Stanley, C. (2006). Coloring the academic landscape: Faculty of color breaking the silence in predominantly white colleges and universities. American Educational Research Journal, 43(4), 701-736.

Thomas, S. L., \& Heck, R. H. (2001). Analysis of large-scale secondary data in higher education research: Potential perils associated with complex sampling designs. Research in Higher Education, 42(5), 517-537. 


\section{Macrothink}

International Journal of Education

ISSN 1948-5476 2012, Vol. 4, No. 2

Turner, C., Sotello, V., González, J.C., \& Wood, J. L. (2008, Sep). Faculty of color in academe: What 20 years of literature tells us. Journal of Diversity in Higher Education, 1(3), 139-168. http://dx.doi.org/10.1037/a0012837

Vardi, I. (2009). The impacts of different types of workload allocation models on academic satisfaction and working life. Higher Education, 57(4), 499 -508. http://dx.doi.org/1893382331.

\section{Copyright Disclaimer}

Copyright reserved by the author(s).

This article is an open-access article distributed under the terms and conditions of the Creative Commons Attribution license (http://creativecommons.org/licenses/by/3.0/). 